\title{
The Moderating Role of Individual Cultural Values on the Relation between TPB Predictors and Entrepreneurial Intention: Evidence from Egypt and Scotland, UK
}

\author{
Rasha H. A. Mostafa \\ Faculty of Business, Ain Shams University \\ dr.rasha.h.mostafa@bus.asu.edu.eg
}

\begin{abstract}
Based on the Theory of Planned Behavior (TPB), the purpose of this study is to identify the antecedents of entrepreneurial intentions (EI) of university students in both Egypt and Scotland, UK. In addition, the research investigates the moderation role of individual cultural values and nationality on the relation between TPB cognitive predictors and entrepreneurial intention. Data was collected using self-administered questionnaire from 243 Egyptian university students. Whereas, Web survey was applied to collect data from 159 Scottish, UK university students. Structural Equation Modelling was applied to examine the research proposed model. The results confirm that both of attitude and perceived behavioral control are significant antecedents of Egyptian students' entrepreneurial intention. Yet, in the case of Scotland, UK, attitude was reported as the sole predictor of entrepreneurial intention. In addition, students 'individual cultural values did not moderate TPB cognitive predictors entrepreneurial intention relation in both samples, meanwhile, nationality did. The study offers theoretical contribution by examining the moderating role of cultural values at the individual level, as well as contextual contribution by validating the research model in a cross-cultural setting namely: Egypt and Scotland, UK, were both represent two diverse cultural clusters in terms of
\end{abstract}


their rankings on Hofstede's cultural dimensions index. In addition, they both represent distinct types of economies i.e. efficiency versus innovation driven economies respectively.

Keywords: Culture, Individual cultural values, Theory of Planned Behavior, Entrepreneurial intention, Nationality, University students, Egypt, Scotland, UK

\section{Introduction}

Entrepreneurship has become more important than ever in recent years. The strengthening of small and medium-size enterprises (SME's) via globalization and information technology have acted to ensure entrepreneurship remains a significant area of research (Sesen, 2013).There is consensus among governments, practitioners and researchers that cultural context shape entrepreneurial attitudes and intentions (European Commission, 2012, Shinnar et al., 2012).

Several authors argued in favor of developed countries benign environments that foster and nurture entrepreneurship as opposed to developing countries hostile ones (e.g. Valliere, 2014; Bandera et al., 2018; Alammari, 2019; Ezeh et al., 2019). Nonetheless, based on the Global Entrepreneurship Monitor (GEM), Bosma and Levie (2009) noticed that nearly one third of the start-ups in developing countries are driven by necessity as opposed to 17 per-cent in developed ones. Egypt is no difference where 42.7 per cent of early stage entrepreneurs remain motivated by necessity instead of opportunity due to the absence of work alternatives (GEM Egypt 2017-2018). Such result emphasizes that turbulent and unsettled contexts in some developing countries, along with political unrest may very well serve as a fertile soil for entrepreneurial opportunities and encourage senior university students and graduates to become self-employed, as opposed to more settled and established milieu in developed countries (e.g. Bezgodov, 1999; Jones et al., 2008; Iakovleva, 2007; Iakovleva et al., 2011). 
Egypt acknowledges entrepreneurship for its vital role in job creation, opening-up opportunities for youth, and stimulating innovation that contribute directly to the country economic prosperity (Global Entrepreneurship Monitor (GEM), Egypt National Report, 2016-2017, 2017-2018). According to GEM Egypt National Report (2017-2018), the country is an efficiency driven economy, where total early-stage entrepreneurial activity (TEA), indicating the percentage of 18-64 years old population that is involved in starting a business rate in Egypt was 13.3 per cent, ranking 19, slightly higher than the global average of 12.3 per cent. In addition, entrepreneurial intention rate is also high; where 55.5 per cent of Egyptian non-entrepreneurs surveyed had interest in, or intentions towards starting a business within the next three years. This score comes second among all GEM countries surveyed ( 65 country), and more than double the global average.

Furthermore, overall Egyptian societal values and attitudes increasingly support entrepreneurship as a positive and desirable activity where it is perceived as a good career choice by 75.9 per cent of Egyptians (GEM 2017-2018), indicating the growth of the entrepreneurial culture, especially among youth who perceived it as a way forward towards economic independence where unemployment rate accounted for 9.2 per cent in the second quarter of 2020 according to CAPMAS Egypt 2020 (http://english.ahram.org.eg/News/369332.aspx).

Additionally, the attention given to entrepreneurship in Egypt has positively improved its ecosystem measures such as: access to finance; government policies support and relevance; and cultural and social norms. Yet, entrepreneurship education at school and universities remains low, where Egypt consistently ranked at the bottom of all GEM countries from 2012 to 2017 (GEM 20172018). 
Despite entrepreneurship phenomenon importance, noticeably, there is dearth of research on students' entrepreneurial intentions in emerging and developing (efficiency-driven) countries compared to their developed (innovation-driven) counterparts (Iakovleva et al., 2011; Aleksandrova et al., 2020). The few studies conducted in developing (efficiency-driven) countries to date researched South Africa students (e.g. Gird and Bagraim, 2008), Polish students (e.g. Jones et al., 2008), and Chinese students (e.g. Wu and $\mathrm{Wu}, 2008$ ).

Hence, the current research is an attempt to fill this gap, besides answering the call brought forward from some scholars to examine the moderating role of culture on entrepreneurial intention (Urban, 2004; Liñán and Chen, 2009; Siu and Lo, 2013). Consequently, the existing study conducts a cross cultural investigation into the moderating role of Egyptian and Scotland, UK university students' cultural values as well as nationality on the relation between Theory of Planned Behavior (TPB) cognitive predictors and entrepreneurial intentions. Hofstede's (1998) cultural dimensions framework is applied. The rationale behind focusing on Egypt and UK is that they represent two diverse cultural clusters in terms of their rankings on Hofstede's four dimensions of individualism (IDV), uncertainty avoidance (UA), power distance (PD), and masculinity (MAS). In addition, they both signify distinct types of economies (i.e. efficiency versus innovation driven economies) respectively.

The socio-cognitive Theory of Planned Behaviour (TPB) developed by (Azjen, 1998,1991) regards attitudes, subjective norms and perceived behavioural control as antecedents to behavioural intentions. TPB has proven to perform appropriately and fits well in researching students' entrepreneurial intentions globally which is the behavior under research in this study (e.g. Nikou et al., 2019; Lortie and Castogiovanni, 2015; Linan and Chen, 2009). Entrepreneurial intention is quite dynamic and has the power to predict actual entrepreneurial behavior (Fayolle and 
Linan, 2014; Kautonen et al., 2015; Ligouri et al., 2018). Meanwhile, Linan et al. (2011) and Joensuu-Salo et al. (2020), in longitudinal studies, found that entrepreneurial intention is stable over time, hence proves its strength to predict subsequent behaviour and even alter previous behaviour tendencies. This is in consonance with Krueger et al. (2000, p. 411) who stated that "intentions have proven the best predictor of planned behavior, particularly when that behavior is rare, hard to observe, or involves unpredictable time lags". Consequently, it deemed appropriate to investigate university students entrepreneurial intentions antecedents in order to provide both researches and policymakers with significant insights as why some students will pursue entrepreneurial career and engage in an entrepreneurial behavior while others will not (Sesen, 2013; Armstrong, 2014; Maresch et al., 2016).

To this end, this paper aims at the following: First, validates and verifies the cross-cultural generalizability of the Theory of Planned Behaviour (TPB) parameters. Second, investigates any similarities and/or differences in the pattern of influence of TPB cognitive predictors on Egyptian and Scotland, UK university students' entrepreneurial intentions. Finally, examines the moderating role of individual cultural values and nationality on the relation between TPB cognitive predictors - entrepreneurial intentions among Egyptian and Scotland, UK university students. The current study offers theoretical (examines individual cultural values); contextual (e.g. Egypt and UK), and methodological (e.g. applying structural equation modelling approach) contributions by extending TPB to the Egyptian context.

The rest of the paper is organized as follows. Theoretical background and hypotheses development are outlined in the next section. Then, research methodology followed by data analyses and results are drawn. Afterward, discussion and conclusions are presented. Finally, the research concludes with significant implications, limitations and recommendations for future research. 


\section{2- Theoretical Background and Hypotheses}

\section{Development}

2-1 Theory of Planned Behavior (TPB) and Entrepreneurial Intention

The literature identified two models for examining entrepreneurial intention behavior namely: Theory of Planned Behavior (TPB) developed by Ajzen (1989, 1991), and Entrepreneurial Event Model (EEM) presented by Shapero and Sokol (1982) (e.g. Chen et al., 2015; Miralles et al., 2015). Yet, TPB has been extensively applied in the entrepreneurship field due to its ability to predict entrepreneurial behavior (e.g. Iakovleva et al., 2011, Shinnar et al., 2012; Schlaegel and Koenig, 2014; Kautonen et al., 2013; Kautonen et al., 2015; Van Gelderen et al., 2015). In addition, it considers both social and personal factors to justify behavioral intentions (e.g. Fini et al., 2012; Maes et al., 2014).

Thus, according to TPB, entrepreneurial intention (EI) is a function of entrepreneurial attitude (EA), subjective norms (SN) which reflect the social pressure the individuals encounter in order to either perform, or not the entrepreneurial behavior, and perceived behavioral control (PBC) where the individuals believe that they have control over the entrepreneurial behavior.

The current study adopts Thompson's (2009) definition of entrepreneurial intention (EI) as "self-acknowledged conviction by a person that s/he intends to set up a new business venture and consciously plans to do so at some point in the future" (p. 676).

However, the effect of TPB cognitive predictors on EI is far from being consistent, where some authors reported significant positive associations (e.g. Paray and Kumar, 2020; Ferri et al., 2019; Farook et al., 2018; Utami, 2017; Aloulou, 2016; Kautonen et al., 2015; Karimi et al., 2014; Yang, 2013; Solesvik, 2013; Iakovleva et al., 2011). While, others revealed that attitude is the only antecedent to EI (e.g. Shahab et al., 2019; Miranda et al., 
2017; Do and Dadvari, 2017; Haus et al., 2013). Although, Siu and Lo (2013) found insignificant effect of attitude on Chinese entrepreneurial intentions.

Whereas, Fayolle and Gailly (2005) and Linan (2005), Wu and Wu (2008), Solesvik et al. (2012), Maresch et al. (2016), AlMamary et al. (2020), Entrialgo and Iglesias (2020), and Aleksandrova et al. (2020) emphasised the significant effect of both attitudes and PBC on EI among Chinese, Ukrainian students, Austrian, Saudi Arabian and Russian's respectively. Likewise, Eid et al. (2019) report a significant positive association between PBC and entrepreneurial intentions among United Arab Emirates national business and engineering undergraduate students

On the other hand, SN were sometimes found to be a direct predictor of EI (e.g. Moriano et al., 2012; Engle et al., 2010; Siu and Lo, 2013; Maresch et al., 2016; Eid et al., 2019; Ephrem et al., 2019). While in another, they showed indirect effect via attitude and PBC (e.g. Linan and Chen, 2009; Srivastava and Misra, 2017). Occasionally, SN reported insignificant association with EI (e.g. Linan and Chen, 2009; Solesvik et al., 2012; Esfandiar et al., 2019; Al-Mamary et al., 2020; Entrialgo and Iglesias, 2020; Aleksandrova et al., 2020).

Given Ajzen (1991) assertion that TPB cognitive predictors influential effects are situational, and likely to differ across behaviours, in addition to the mixed results highlighted above, the following hypotheses are proposed:

H1: there is a significant positive relationship between Egyptian and Scottish students' attitudes and entrepreneurial intention H2: there is a significant positive relationship between Egyptian and Scottish students' subjective norms and entrepreneurial intention 
H3: there is a significant positive relationship between Egyptian and Scottish students perceived behavioural control and entrepreneurial intention

H4: There are significant differences between Egyptian and Scottish students with respect to:

a- Entrepreneurial attitude

$b$ - Subjective norms

c- Perceived behavioural control

$d$ - Entrepreneurial intention

\subsection{Culture and Entrepreneurship}

Although there is no universally accepted definition of culture, however, Hofstede's (2001) definition has been extensively used where the author defined culture as "the collective programming of the mind that distinguishes the members of one group or category of people from another."(p.9). In this sense culture is a way of categorizing people who shared same values, beliefs and perceptions as a result of getting exposed to similar life experiences which influence their behavior and differentiate them from their opponents in other cultures (Hofstede, 1980, 1981, 1998; Smith, 2002; Shinnar et al., 2012).

Number of studies have recognized that national culture stimulates innovation and growth (e.g. Rauch et al., 2013); affects the individual's value system and helps him/her developing entrepreneurial skills (e.g. Bull and Willard, 1993); allows individual's to identify business opportunities (e.g. Baker, Gedajlovic and Lubatkin, 2005; Hechavarria and Reynolds, 2009); develops entrepreneurial beliefs and intentions, and further behaves entrepreneurially (e.g. Siu and Lo, 2013; Kreiser et al., 2010; Madichie, Nkamnebe and Idemobi, 2008; Devonish et al., 2010; Bogatyreva et al., 2019).

Based on Hofstede's (1980) cultural dimensions framework, Busenitz and Lau (1996) and Hayton et al. (2002) reported that "researchers have hypothesized that entrepreneurship is 
facilitated by cultures that are high in individualism, low in uncertainty avoidance, low in power-distance, and high in masculinity"(p.34). Hence, according to Egypt and Scotland, UK ranks on all four dimensions emphasized as follows: Individualism - IDV - (25), (89), Uncertainty Avoidance - UA (80), (35), Power Distance - PD (70), (35), and Masculinity MAS (45), (66) respectively (Hofstede Centre, 2015). It could be inferred that as opposed to Scotland, UK, Egypt is not the type of culture that foster entrepreneurship as further indicated hereunder.

According to Hofstede $(1980,2001)$ individualism "pertains to societies in which the ties between individuals are loose: everyone is expected to look after himself or herself and his or her immediate family". As opposed to UK, Egypt ranks 25 on individualism/collectivism index is low enough to consider it a collectivistic country, where individual's self-image is defined in terms of 'we' instead of 'I'. The Egyptians' tend to establish longterm relations with their close family and the extended one, as well as with friends, and neighbours.

Uncertainty Avoidance is "the extent to which the members of a culture feel threatened by uncertain or unknown situations". Egyptians' fear ambiguous situations, they need to feel secured, hence they prefer to follow written rules or unwritten norms. Such cultural value doesn't necessarily encourage innovation and venture creation.

Power Distance is defined as "the extent to which the less powerful members of institutions and organizations within a country expect and accept that power is distributed unequally". While comparing Egypt's rank with UK, it is very clear that hierarchical system is highly accepted in Egypt, where those lie at the top of the hierarchy dominate the power and the authority. 
Masculinity "represents the dominant male sex role pattern in the vast majority of traditional and modern societies". "high score (Masculine) on this dimension indicates that the society will be driven by competition, achievement and success, with success being defined by the winner / best in field - a value system that starts in school and continues throughout organisational life. A low score (Feminine) on the dimension means that the dominant values in society are caring for others and quality of life". While looking at the ranks of both countries under investigation, it appears that Egypt is, relatively, a feminine country, where caring for others and quality of life are dominating the Egyptian culture, as opposed to competition and achievement in more masculine countries like Scotland, UK.

Despite the extensive use of Hofstede's (1980) cultural dimensions, their relationship with entrepreneurship is far from being consistent (Giacomin et al., 2010). Where some researchers report positive association between individualism (Levenburg and Schwarz, 2008; Van Hooft and De Jong, 2009) and masculinity (Levenburg and Schwarz, 2008) and entrepreneurial behaviour. While others assert that collectivism influences entrepreneurial behavior in collectivism dominating countries (Tiessen, 1997; Nguyen et al., 2010); affects the entrepreneurial potential of United Arab Emirates business university students (Zeffane, 2014), and it is the driving force of competitiveness and entrepreneurial intentions among Balinese and American undergraduate college students (Houston et al., 2012).

Meanwhile, the association between cultural values and entrepreneurial intentions has been well recognized in the literature. For instance, Baughn et al. (2006) reported significant differences in entrepreneurial intentions among Vietnamese, Philippine and Chinese business students. This result revealed that, although the three countries under investigation are in the same continent, and they may share some cultural values, however it seems that differences at the country level have more 
power over entrepreneurial intention. Correspondingly, Solesvik et al. (2014) and Thornton et al. (2011) emphasized the effect of cultural factors on individual's entrepreneurial intention and his/her decision to become an entrepreneur and to start a new business. Similarly, DePillis and Reardon (2007) asserted that cultural perceptions of entrepreneurship affect individual's entrepreneurial intention level. Likewise, Giacomin et al. (2010) examine American, Asian and European university students, Goktan and Gunay (2011) investigate Turkish and American respondents, and Shinnar et al. (2012) study Chinese, American and Belgium students, they all confirmed the significant interrelationship between culture and entrepreneurial cognition and intention level that is highly likely to vary by country. In contrast, Pruett et al. (2009) indicated the limited predictive ability of cultural dimensions in justifying Americans, Chinese and Spanish university students' entrepreneurial intentions.

Evidently, Hofstede's (1980, 2001) cultural dimensions scores are country level based. However, the present study is an attempt to examine these dimensions at the individual level. The researcher underlying argument is in consonance with Morales and Holtschlag (2013) who emphasizes that not always individuals brought up and living in a country - in our case Egypt and UK- will exhibit their home country dominating cultural values. Since, an individual nationality does not necessarily mean that $\mathrm{s} / \mathrm{he}$ is identified with only one culture. Given the increased level of mobility, global migration that allow many people to have dual nationality nowadays and get highly exposed to many other different cultures (Berry, 2011). Accordingly, individuals' cultural values, as opposed to country-level ones, may reveal different effects towards entrepreneurial intention and behavior within the two countries under investigation.

Therefore, based on the above literature and Hofstede's classification of both Egypt and UK cultural values, the following hypothesis is anticipated: 
H5: There are significant differences between Egyptian and Scottish students with respect to individual cultural values as follows:

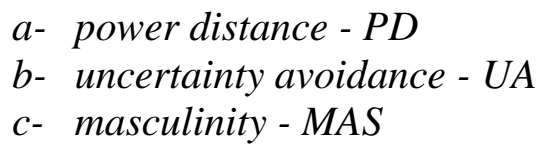

\subsection{Theory of Planned Behaviour, Entrepreneurial Intentions and Cultural Values}

Some scholars reported the influence of national culture on TPB predictors and entrepreneurial intentions in different countries namely: attitude (e.g. Beeka and Rimmington, 2011; Farrukh et al., 2019), perceived behavioral control (e.g. Farrukh et al., 2019), and subjective norms (Autio, Pathak and Wennberg, 2013; George and Zahra, 2002; Stephan and Uhlaner, 2010; Farrukh et $a l ., 2019)$. Whereas, few studies recognized the moderation effect of culture on the relation between TPB predictors and entrepreneurial intentions. For instance, Mitchell et al. (2000) reported the moderation effect of power distance on the relation between entrepreneurial capability-related cognitive constructs and entrepreneurial decisions. Likewise, Valliere (2014) revealed the moderation effect of cultural values on the relation between individuals' attitude, social norms, perceived behavioural control and entrepreneurial intentions. The researcher asserted that culture plays vital role in shaping individuals' entrepreneurial attitudes. Accordingly, it either paves or hinder the road for entrepreneurial behavior. In the same vein, Liñán and Chen (2009), in their cross-national study in Spain and Taiwan, found that uncertainty avoidance moderates the relation between entrepreneurial self-efficacy and entrepreneurial intentions. Yet, the authors failed to establish the moderating effect of individualism/collectivism on subjective norms - entrepreneurial intentions relationship. Hence, based on the literature, the following hypotheses are established: 
H6-a Individual cultural values (i.e. PD, UA, MAS) moderate the relation between Egyptian and Scottish students' attitudes towards entrepreneurship, subjective norms, perceived behavioral control and entrepreneurial intention

H6-b Nationality moderates the relation between Egyptian and Scottish students' attitudes towards entrepreneurship, subjective norms, perceived behavioral control and entrepreneurial intention

\section{Research Methodology}

\subsection{Conceptual Model}

Figure 1 depicts the study conceptual model and the hypothesized relations. It emphasizes the theory of planned behavior predictors (i.e. attitude, subjective norms and perceived behavioral control) as antecedents to entrepreneurial intention. In addition, nationality and cultural values (i.e. power distance, uncertainty avoidance and masculinity) appear as moderators between TPB predictors and entrepreneurial intention. The researcher examined and compared the above-mentioned relations in both developing and developed contexts namely: Egypt and Scotland, UK respectively.

\subsection{Sample and Data Collection}

The literature underscored that university students have been widely used as a sample in entrepreneurship research (e.g Litzky et al., 2020; Entrialgo and Iglesias, 2020; Shahab et al., 2019; Do and Dadvari, 2017; Maresch et al., 2016).

Accordingly, the current research population consists of undergraduate business school students in their third and fourth year in two major public universities. The first one located in Cairo, Egypt with a population of 2000 students in the English section, while the other is in Scotland, UK with a population of 595 students. Both countries were chosen as the earlier represents the Arab cluster, which is highly under-researched in the 
entrepreneurship field. Whereas, the latter represents the European cluster (Hofstede, 1980).

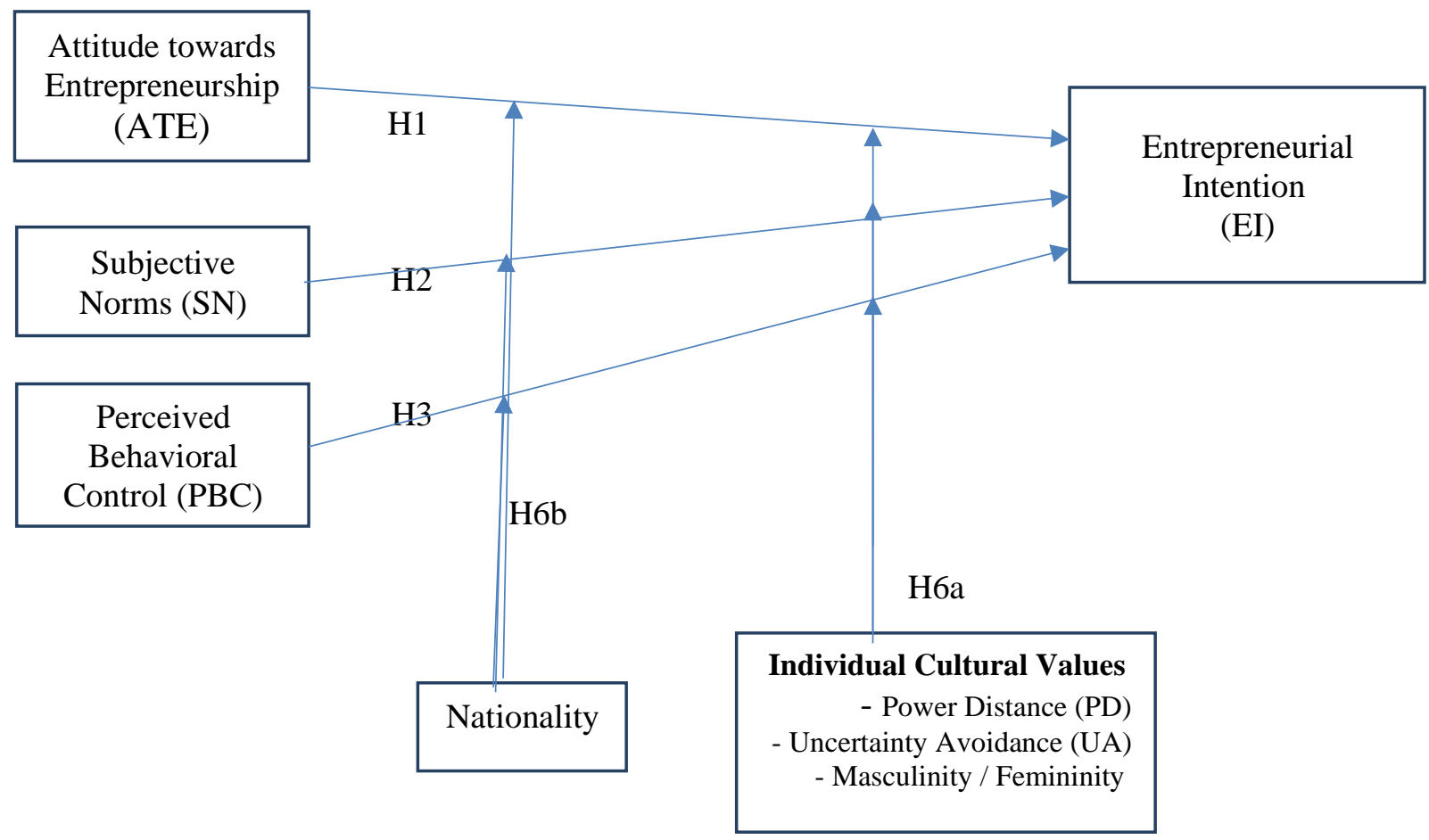

Figure 1. Conceptual Model

The data collected allowed for comparison between the two clusters. In both cases, the students filled in the questionnaire voluntarily. Where, self-administered questionnaire was used to collect data from a convenience sample of 243 Egyptian student. the questionnaire was completed during class time using paper and pencil. However, in Scotland, UK case, a Web-based survey was administered, where a link to the survey was mailed to 585 students, from which 159 were completed, yielding $27 \%$ response rate. 
To Examine the research hypotheses, the researcher adapted measurement scales from the preceding literature. Entrepreneurial intentions were measured using six-item scale developed by Liñán and Chen (2009). An example item reads: "I'm determined to create a firm in the future". Attitude towards entrepreneurship, subjective norms, and perceived behavioral control were measured using five-item scale, three-item scale, and six-item scale respectively developed by Liñán and Chen (2009). In addition, cultural values scale was measured using five-item scale measuring Power Distance, another five-item scale measuring Uncertainty Avoidance, and four-item scale measuring Masculinity respectively developed by Yoo et al. (2011). All items used 5-point Likert scale anchored from 1 "strongly disagree" to 5 "strongly agree".

Back translation method was applied to ensure questionnaire consistency, and to validate the interpretation of the scales used. Whereas, the questionnaire was developed in English then translated into Arabic, and back again into English by the researcher and a bilingual translator. Prior to final distribution, the research instrument was pre-tested on 30 Egyptian respondents and 25 Scottish ones to avoid any ambiguous questions and improve the measurement scales. Accordingly, few statements were modified for further clarification.

The final samples encompassed 243 and 159 valid cases from Egypt and Scotland, UK respectively. Both samples were skewed in favour of female respondents as they represented 69.5 per cent of the Egyptian sample and 62.8 per cent of the Scottish one. Further, 91.7 per cent of the Egyptian students fall between 18 and 22 years old as opposed to 76.7 per cent of the Scottish students. In addition, 21 per cent of the Egyptian students were introduced to entrepreneurship education, as opposed to 72 per cent of their Scottish counterparts who reported being introduced to entrepreneurship education at the university level. 


\section{Data Analysis and Results}

The analysis of the research data was carried out in two steps as recommended by Anderson and Gerbing (1988). First the analysis of the measurement model was conducted, followed by the analysis of the structural model by covariance-based Structural Equation Modeling (SEM) using AMOS 22. Then later, the moderation effect of cultural values and nationality was examined.

\subsection{Analysis of the Measurement Model}

Confirmatory Factor Analysis (CFA) was undertaken to address the issues of convergent and discriminant validity (Anderson and Gerbing, 1988; Jöreskog and Sörbom, 1993) of the measurement model. The latter encompassed entrepreneurial intention, attitude, subjective norms, perceived behavioral control, power distance, uncertainty avoidance and masculinity.

CFA results yielded the removal of some research constructs items in both Egyptian and Scottish samples due to their low standardized factor loading which was below the minimum recommended cut-off point of .5 emphasized by Hair et al. (2010). However, Subjective Norms (SN) and Power Distance (PD) items loaded successfully on their respective factors in both samples. Tables 1 and 2 depict the confirmatory factor analysis results in both research samples. All items loaded successfully on a single factor with a standardized loading equivalent to, or greater than 0.5 with values ranging from .514 to .804 in the Egyptian sample, and .50 to .935 in the Scottish sample at $99 \%$ significant level, hence revealing strong convergent validity.

Further, the reliability of all research constructs was examined using Cronbach's alpha. The values exceeded the minimum recommended value suggested by (Nunnally, 1978; Hair et al., 2010), and the overall alpha value accounted for 0.829 in both samples (see Tables 1 and 2). 
Table (1): Confirmatory Factor Analysis and Cronbach Alpha Results for the Measurement Model (Egypt Sample) Table (2): Confirmatory Factor Analysis and Cronbach Alpha Results for the Measurement Model (Scotland, UK Sample)

Tables 3 and 4 hereunder highlighted the composite reliability (CR) and the average variance extracted (AVE) for the research constructs in Egypt and Scotland, UK respectively. It was noticed that CR for all research constructs in both samples exceeded the threshold 0.7 suggested by Bagozzi (1994). However, the AVE values were greater than 0.45 as recommended by (Netemeyer $e t$ al., 2003). The results confirmed internal consistency and convergent validity.

Table (3): Discriminant and Convergent Validity of the Study Constructs (Egypt Sample)

Table (4): Discriminant and Convergent Validity of the Study Constructs (Scotland, UK

The results of the analysis of the measurement model provided satisfactory evidence to proceed further with the analysis of the structural model.

\subsection{Analysis of the Structural Model}

Structural Equation Modelling (AMOS) version 22 was used to examine the research hypotheses. Number of fit indices and from different classes were used to assess the overall models fit and to overcome the limitations of each index (Marsh, Balla, and Hau, 1996; Jaccard and Wan 1996). Tables 5 and 6, as well as Figures 2 and 3 illustrate the path coefficients and significances for the overall models in both samples under investigation. 
Table (5): Path Coefficients and Significances (Egypt Sample) Table (6): Path Coefficients and Significances (Scotland, UK Sample)

The results showed that Chi-square values of Egypt and Scotland, UK respectively $\{\chi 2 / \mathrm{d} f \quad(103.831 / 84 ; p=.07)$ and $\{\chi 2 / \mathrm{d} f$ $(125.51 / 113, p=.198)$ were statistically insignificant at 0.05 level. Whereas, all the fit indices employed have fallen within the recommended range, hence ensuring good models fit. The results came as follows: NFI $\geq .90$ (0.90 and 0.93); CFI $\geq 0.90$ (0.97 and $0.99)$; TLI $\geq 0.90$ (0.97 and 0.99); RMSEA $\leq 0.08$ (0.03and 0.02); IFI (0.98 and 0.99); PCFI $\geq 0.60$ (0.79 and 0.83) for both Egypt and Scotland, UK respectively.

The results lend support to $H I$ where Egyptian and Scottish students' ATE positively and significantly affect their EI as follows $(\beta=0.697, \mathrm{t}=6.523, p<0.001)$ and $(\beta=0.777, \mathrm{t}=8.641$, $p<0.001)$. However, contrary to $H 2, \mathrm{SN}$ for students from both samples had insignificant effect on EI. Hence, $H 2$ was rejected. Further, the structural model provided partial support to $H 3$, where PBC positively and significantly influences Egyptian students' EI only $(\beta=0.18, \mathrm{t}=2.492, p<0.01)$, while insignificant result was observed among their Scottish counterparts. 


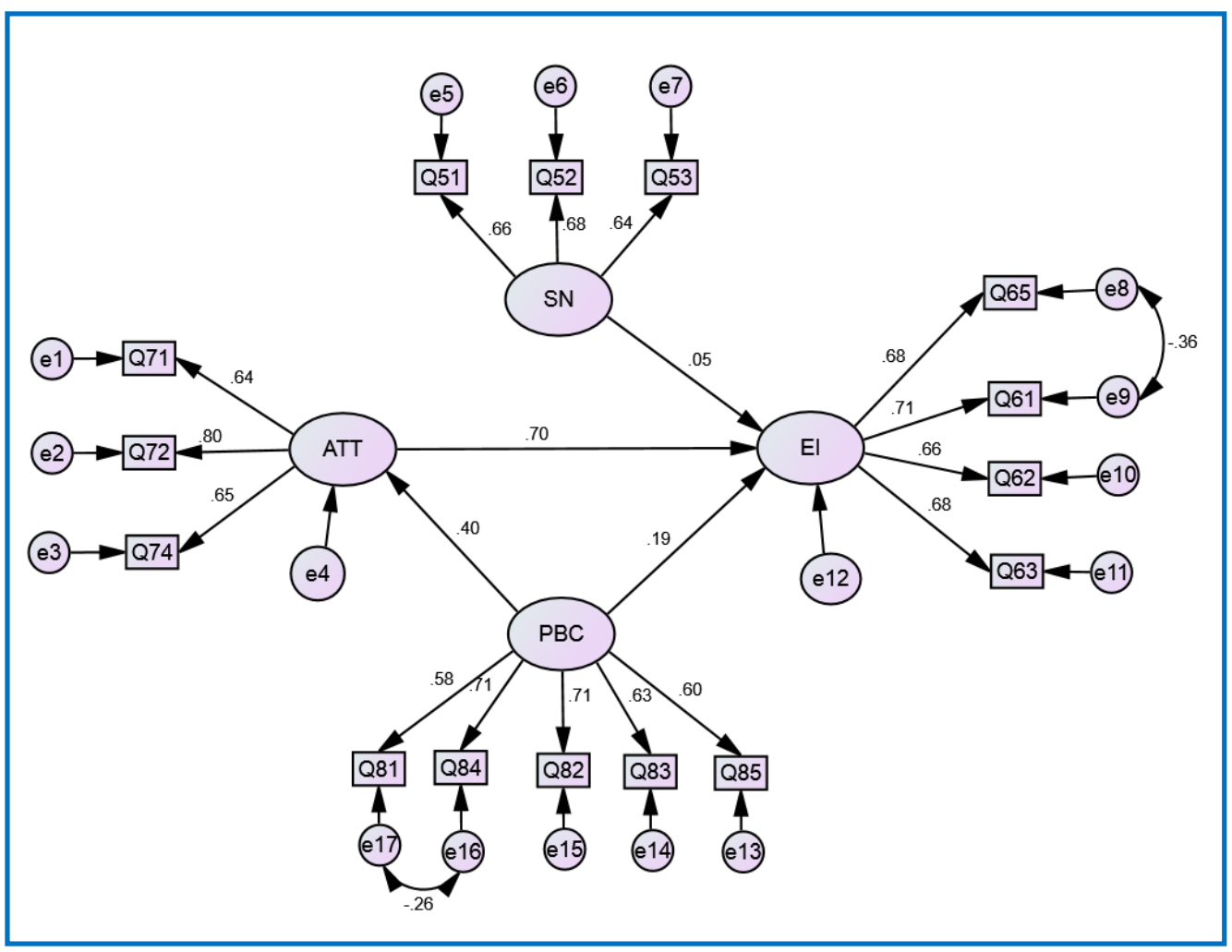

Figure 2. Structural Model for Egypt 


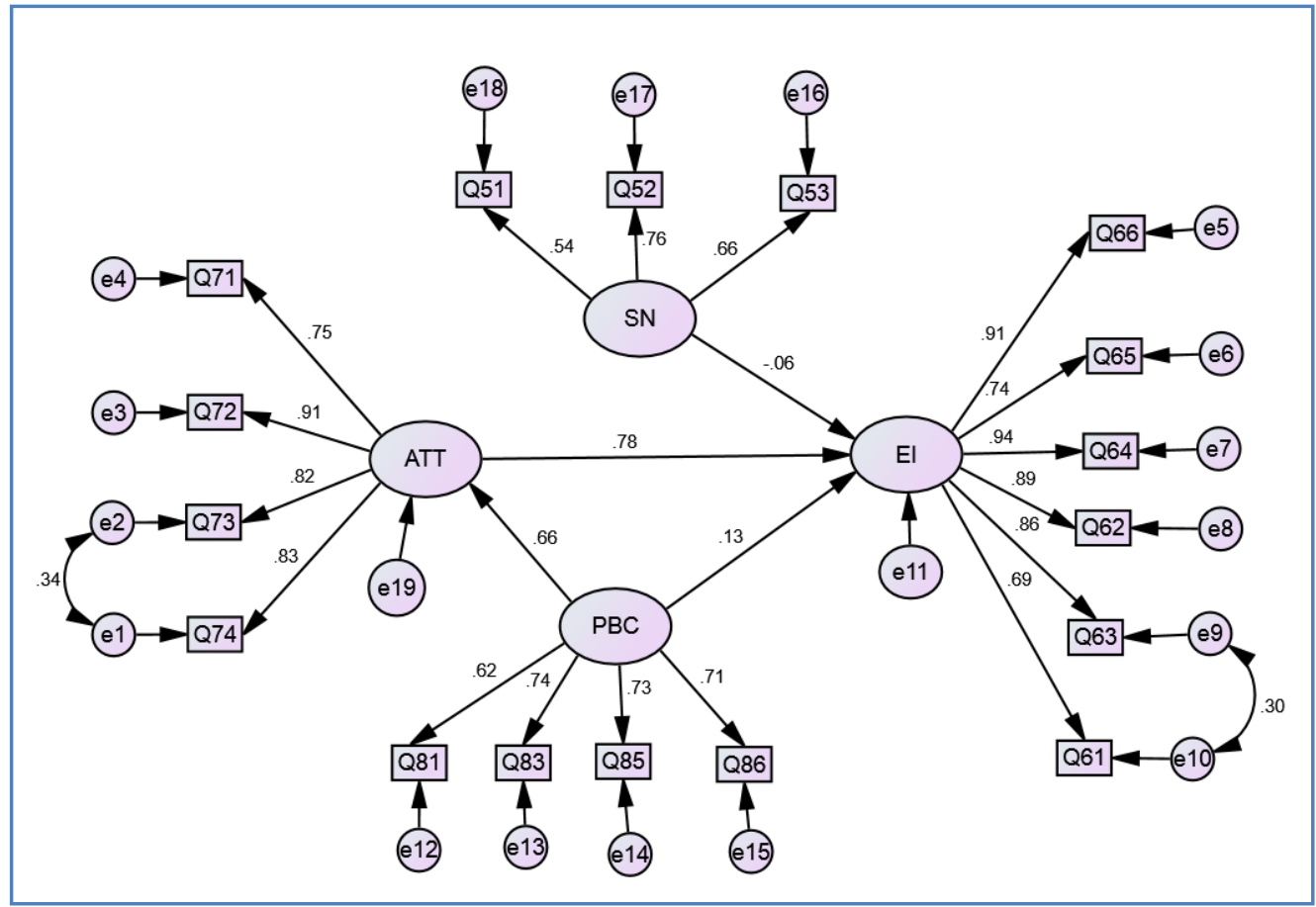

Figure 3. Structural Model for Scotland, UK

T-test was conducted to examine $H 4$ and $H 5$. The results revealed no significant differences between Egyptian and Scottish students with respect to TPB cognitive predictors, yet significant differences were realized regarding EI and individuals' cultural values namely: power distance, uncertainty avoidance and masculinity. Accordingly, $H 4$ was partially supported while full support was given to $H 5$ (see Table 7).

Table (7): The Differences between Egyptian and Scottish, UK Students with Respect to TPB Predictors, Entrepreneurial Intentions and Cultural Values 


\subsubsection{Moderating Effects of Individuals Cultural Values}

In order to examine the moderating effect of individuals cultural values on the relation between attitudes towards entrepreneurship, subjective norms and perceived behavior control and entrepreneurial intentions, a multi-group analysis was conducted using AMOS 22. The significant/non-significant differences in the Chi-square values between the unconstrained model and the constrained one determine the existence/nonexistence of the moderation effect.

The two samples of the Egyptian and the Scottish students were divided into two groups using the median score of the respondents with respect to each cultural value moderator (i.e. power distance; uncertainty avoidance; masculinity/femininity). Respondents below the median point represent those who score low on a cultural value and vice versa.

The results show significant relation between ATE and EI among respondents with low and high levels of PD, UA and MAS among Egyptian and Scottish students. In addition, PBC has significant relation with EI among Egyptian students with low levels of PD, Scottish students with high levels of UA, and Egyptian and Scottish students with high levels of MAS. Finally, SN have significant negative relation with EI among Scottish students with low levels of PD (see Tables, 8, 9, 10, 11, 12 and 13).

However, despite the strengths of these dependencies the results show insignificant moderation effect of individual cultural values in the relation between TPB cognitive predictors and EI among Egyptian and Scottish students. Thus, H6a has not been supported (see Tables $(8,9,10)$ and Tables $(11,12,13)$.

Following the same procedure, the moderating effect of nationality on the relationship between TPB cognitive predictors and Egyptian and Scottish students' EI was calculated. The result indicates the existence of significant moderation in both samples 
(see Table 14). Though the path coefficient for ATE among Egyptian students was greater than their Scottish counterparts. In addition, significant moderation effect was emphasized in the relation between PBC and Scottish students' EI only. Yet, insignificant moderation results were underscored in the relation between SN and EI among students from both samples under investigation. Thus, $H 6 b$ is partially supported.

Table (14): Moderating effect of Nationality Among TPB Predictors and Entrepreneurship Intention

\section{Discussion and Conclusions}

The purpose of this study is to examine the moderating role of individual cultural values and nationality on the relation between TPB cognitive predictors and entrepreneurial intent among Egyptian and Scottish university students.

The current research reveals some interesting results. To commence with, the Egyptian students unearth significant positive attitude and perceived behavioral control towards entrepreneurial intent. These results imply that being an entrepreneur entails great advantages and satisfactions to them. In addition, they have confidence in themselves in developing an entrepreneurial project, starting a viable firm, and controlling the creation process. These results are in consonance with the literature where Maresch et al. (2016) and Aleksandrova et al. (2020), among others, reached the same outcome among Austrian university students and Russian's adult population respectively.

Meanwhile, attitude appears to be the only antecedent that positively affect UK students' entrepreneurial intent. This result implies that they are attracted to pursue an entrepreneurship career whenever the window of opportunity is open. This is consistent with previous studies such as Shahab et al. (2019), who found same result among Chinese and Spanish university students; likewise, Do and Dadvari (2017) reported similar conclusion among Taiwanese university students. Even, Spanish 
university academics stated the same result as highlighted by (Miranda et al., 2017).

However, regarding the effect of subjective norms on entrepreneurial intention, the literature was far beyond coherent. Accordingly, the current study shows insignificant association between SN and entrepreneurial intention among Egyptian and Scottish university students. The result is corresponding to Esfandiar et al. (2019) outcome concerning the Iranian university students and Aleksandrova et al. (2020) conclusion regarding Russian's adult population. This result could be interpreted considering previous studies conclusion vis-a-vis the positive correlation between attitude and subjective norms (e.g. Maresch $e t$ al., 2016; Schlaegel and Koenig, 2014), as well as between perceived behavioral control and subjective norms (e.g. Entrialgo and Iglesias, 2020). So, SN effect on entrepreneurial intention per $s e$ might be obscured in its indirect association with both attitude and perceived behavioral control.

In addition, the result indicates that individual cultural values (PD, UA, MAS) do not moderate the relation between TPB cognitive predictors and entrepreneurial intentions among respondents from both countries, however, nationality does. This result points out that it would be better to perceive culture from a holistic perspective that embraces nationwide instead of comprehending it at the individual level. This is in consonance with Hofstede (1983) who stressed on the significance of nationality in people's lives, that makes them psychologically connected with their national culture.

The above result could be interpreted considering number of scholars who have reported that national culture moderates the differences between national groups in terms of reasoning and behaviors (e.g. Hofstede, 2001; House et al., 2004; Schwartz, 1999; Trompenaars and Hampden-Turner, 1998; Pruett et al., 2009; Iakovleva et al., 2011; Bogatyreva et al., 2019; Litzky et al., 2020). 
The literature hypothesized that "entrepreneurship is facilitated by cultures that are high in individualism, low in uncertainty avoidance, low in power-distance, and high in masculinity" (Hayton et al., 2002, p.34). Further, according to Hofstede's cultural dimensions, Egypt and United Kingdom are ranked as follows: Individualism - IDV - (25) (89), Uncertainty Avoidance - UA (80) (35), Power Distance - PD (70) (35), and Masculinity - MAS (45) (66) respectively (Hofstede Centre, 2015).

Following this hypothesis, UK culture index reflects the ideal context to foster and facilitate entrepreneurship as opposed to the Egyptian one. However, the results show that nationality moderates the relation between Egyptian and Scottish, UK students' attitude towards entrepreneurship and their entrepreneurial intent, with the Egyptian students' recording higher level of attitude compared to their counterparts. This outcome contradicts Hofstede (2015) hypothesis regarding categorizing some cultures as more liable and prepared to foster entrepreneurship as opposed to others. In addition, this effect could also be interpreted considering the scarcity of available job opportunities for fresh graduates in Egypt, a status which undergraduates are aware of. Hence, they get themselves prepared and equipped with the skills and knowledge needed to start up their own business. This result is in consonance with GEM (2017-2018) where $42.7 \%$ of early stage entrepreneurs remain motivated by necessity instead of opportunity due to the absence of work alternatives.

In addition, nationality also moderates the relation between Scottish, UK students perceived behavioral control and their entrepreneurial intention. This result reflects the high percentage of UK students (72 per cent) who are introduced to entrepreneurship education at the university level as opposed to their 21 per cent Egyptian counterparts. Such result confirms GEM (2017-2018) report that ranked Egypt at the bottom of all GEM countries participated in the longitudinal study (65 country) 
for both school, college and university levels entrepreneurship education in 2016 and 2017. Consequently, UK students are aware of the necessary practical details to start a firm which in turn make them in control of the creation process, well prepared to start up their own business, in addition they believe in themselves and their ability to succeed in case they started up a business.

This research contributes to the methodological progression of entrepreneurial cognitive research by studying the moderation effect of individuals cultural values and nationality on the relation between TPB predictors and entrepreneurial intention. The study incorporates different cultural orientations in the research model namely: power distance, uncertainty avoidance and masculinity/femininity. Further, it provides extensive empirical support to the applicability of TPB to entrepreneurship research, particularly after examining it on two-country sample namely Egypt and Scotland, UK.

\section{Implications}

The current study emphasizes the magnitude of individual's attitude towards entrepreneurship and perceived behavioral control as motivational factors fostering entrepreneurial intent. Consequently, these motivational factors should be encouraged and embedded in entrepreneurship courses. Particularly that both factors are subject for change and development over time as highlighted by (Wakkee $e t$ al., 2010).

Although the current study did not statistically examine the relation between entrepreneurship education and entrepreneurial intent, yet the high percentage of Scottish students who were introduced to such type of education may have some influence on the results. Accordingly, it is suggested that entrepreneurship courses should be application based where students can acquire, develop and enhance their entrepreneurial skills, knowledge and intentions. In addition, guest speakers and successful entrepreneurs should be invited to entrepreneurship classes as they may act as influential leaders to 
encourage students and make them more confident to become entrepreneurs.

Furthermore, entrepreneurial programs should consider national culture since it is recognized as a significant moderator between some TPB predictors and entrepreneurial intent, particularly with respect to attitude towards entrepreneurship and perceived behavioral control.

\section{Limitations and Future Research}

This study has few limitations that should be acknowledged. First, as this research is cross sectional one that investigated undergraduate students' entrepreneurial intentions. It would be reasonable to continue the research and investigate whether this intention turned into actual behavior and a real start-up after graduation or not. Accordingly, it is suggested that a longitudinal study should take place to examine students at different points before and after graduation.

In addition, although respondents included in this research were business students only enrolled in public universities either in Egypt or Scotland, UK. The researcher believes that entrepreneurship is an interdisciplinary field that should not be restricted to business students, hence future research should include students registered in private universities and in other fields of studies (e.g. science, engineering) with the aim of promoting and encouraging entrepreneurship education that allows students to think creatively, innovatively and outside the box. 


\section{References}

Ajzen, I. (1989), Attitudes, Personality, and Behavior, Dorsey Press, Chicago, IL.

Ajzen, I. (1991), "The theory of planned behaviour", Organizational Behaviour and Human Decision Processes, Vol. 50, pp.179-211.

Ajzen, I. (2002), "Perceived behavioural control, self-efficacy, locus of control, and the theory of planned behaviour", Journal of Applied Social Psychology, Vol. 32 No. 4, pp. 665-683.

Alammari, K., Newbery, R., Haddoud, M.Y. and Beaumont, E. (2019), "Post-materialistic values and entrepreneurial intention - the case of Saudi Arabia", Journal of Small Business and Enterprise Development, Vol. 26 No. 1, pp. 158-179.

Aleksandrova, E. Gerry, C. and Verkhovskaya, O. (2020), "Missing Entrepreneurs: the importance of attitudes and control in shaping entrepreneurial intentions in Russia", Journal of Entrepreneurship in Emerging Economies, Vol.12 No.1, pp.1-33.

Al-Mamary, Y. Abdulrab, M. Alwaheeb, M. and Alshammari, N. (2020), "Factors impacting entrepreneurial intentions among university students in Saudi Arabia: testing an integrated model of TPB and EO", Education + Training, Vol.62 No7/8, pp.779-803.

Aloulou, W. (2016), "Predicting entrepreneurial intention of final year Saudi university business students by applying the theory of planned behavior", Journal of Small Business and Enterprise Development, Vol. 23 No.4, pp.11421164.

Anderson, J. and Gerbing, D. (1988), "Structural equation modelling in practice: a review andrecommended twostep approach", Psychological Bulletin, Vol. 103 No. 3, pp. 411-423.

Autio, E., Pathak, S., and Wennberg, K. (2013), "Consequences 
of cultural practices for entrepreneurial behaviors", Journal of International Business Studies, Vol.44 No.4, pp.334-362.

Bandera, C., Eminet, A., Passerini, K. and Pon, K. (2018), "Using mind maps to distinguish cultural norms between French and United States entrepreneurship students", Journal of Small Business Management, Vol. 56 No. S1, pp. 177196.

Baughn, C.C., Cao, J.R., Le, L.T.M., Lim, V.A., and Neupert, K.E. (2006), "Normative, social and cognitive predictors of entrepreneurial interest in China, Vietnam and the Philippines", Journal of Developmental Entrepreneurship, Vol.11 No.1, pp. 57-77.

Beeka, B.H. and Rimmington, M. (2011), "Entrepreneurship as a career options for African Youths", Journal of Development Entrepreneurship, Vol. 16 No. 1, pp. 145164.

Bezgodov, A. (1999), Entrepreneurship Sociology, Petropolis, St Petersburg.

Bosma, N. and Levie, J. (2009), "Global Entrepreneurship Monitor 2009 global report", available at: www.gemconsortium.org/ (accessed 6 April 2016).

Bogatyreva, K. Edelmanb, L. Manolovab, T. Osiyevskyyc, O. and Shirokovaa, G. (2019), "When do entrepreneurial intentions lead to actions? The role of national culture", Journal of Business Research, Vol. 96, pp.309-321.

Busenitz, L.W. and Lau, C.M. (1996), "A cross-cultural cognitive model of new venture creation", Entrepreneurship Theory and Practice, Vol. 20 No.4, pp. 25-39.

Chen, S.-C., Hsiao, H.-C., Chang, J.-C., Chou, C.-M., Chen, C. -P. and Shen, C.-H. (2015), "Can the entrepreneurship course improves the entrepreneurial intentions of students?", International Entrepreneurship and Management Journal, Vol.11 No.3, pp. 557-569.

DePillis, E. and Reardon, K.K. (2007), “The influence of 
personality traits and persuasive messages on entrepreneurial intention", Career Development International, Vol.12 No.4, pp. 382-96.

Devonish, D. Alleyne, P. Charles-Soverall, W. Marshall, A.Y. and Pounder, P. (2010), "Explaining Entrepreneurial Intentions in the Caribbean", International Journal of Entrepreneurial Behaviour and Research, Vol.16 No.2, pp.149-171.

Do, B. and Dadvari, A. (2017), "The influence of the dark triad on the relationship between entrepreneurial attitude orientation and entrepreneurial intention: A study among students in Taiwan University", Asia Pacifica Management Review, Vol.22 No.4, pp.185-191.

Eid, R. Badewi, A. Selim, H. and El-Gohary, H. "Integrating and extending competing intentions models to understand the entrepreneurial intentions of senior university students", Education + Training, Vol.61 No.2, pp.234-254.

Engle, R.L., Dimitriadi, N., Gavidia, H., Schlaegel, C., Delaoe, S., Alvarado, I., He, X., Buame, S. and Wolff, B. (2010), "Entrepreneurial intent: a twelve-country evaluation of Ajzen's model of planned behavior", International Journal of Entrepreneurial Behaviour and Research, Vol. 16 No. 1, pp.35-57.

Entrialgo, M. and Iglesias, V. (2020), "Entrepreneurial Intentions among University Students:The Moderating Role of Creativity", European Management Review, Vol. 17, pp. 529-542.

Ephrem, A. Namatovu, R.and Basalirwa, E. (2019), "Perceived social norms, psychological capital and entrepreneurial intention among undergraduate students in Bukavu", Education + Training, Vol.61 No.7/8, pp.963-983.

Esfandiar, K. Tehrani, M. Patt, S. and Altinay, L. (2019),

"Understanding an entrepreneurial intention: a developed integrated structural model approach", Journal of Business Research, Vol. 94, pp.172-182.

European Commission (2012), Effects and Impact of 
Entrepreneurship Programmes in Higher Education, European Commission, Brussels.

Ezeh, P.C., Nkamnebe, A.D. and Omodafe, U.P. (2019),

"Determinants of entrepreneurial intention among undergraduates in a Muslim community", Management Research Review, Vol. 43 No. 8, pp. 1013-1030.

Farook, M. Salam, M. Rehman, S. Fayolle, A. Jaafar, N. and Ayupp, K. (2018), "Impact of support of social network on entrepreneurial intention of fresh business graduates: a structural equation modelling approach", Education + Training, Vol. 60 No.4, pp.335-353.

Farrukh, M. Lee, J. Sajid, M. and Waheed, A. (2019),

"Entrepreneurial intentions: the role of individualism and collectivism in perspective of theory of planned behavior", Education + Training, Vol.61 No.7/8, pp.9841000.

Fayolle, A. and Gailly, B. (2005): "Using the theory of planned behaviour to assess entrepreneurship teaching programs: a first experimentation", Centre for Research, Innovation and Strategy, Working Paper 05/2005, Louvain School of Management.

Fayolle, A. and Linan, F. (2014), "The Future of Research on Entrepreneurial Intentions", Journal of Business Research, Vol.67 No.5, pp.663-666.

Ferri, L. Ginesti, G. Spano, R. and Zampella, A. (2019), "Exploring factors motivating entrepreneurial intentions: the case of Italian university students", International Journal of Training and Development, Vol.23 No.3, pp. 202-220.

Fini, R., Grimaldi, R., Marzocchi, G.L. and Sobrero, M. (2012), "The determinants of corporate entrepreneurial intention within small and newly established firms", Entrepreneurship Theory and Practice, Vol. 36 No. 2, pp. 387-414.

George, G., and Zahra, S.A. (2002), "Culture and its 
consequences for entrepreneurship" Entrepreneurship Theory \& Practice, Vol. 26 No.4, pp.5-8.

Giacomin, O. Janssen, F. Pruett, M. Shinnar, R. Llopis, F. and Toney, B. (2010), "Entrepreneurial Intentions, Motivations and Barriers: Differences among American, Asian and European Students", International Entrepreneurship and Management Journal, Vol.7 No.2, pp.219-238.

Gird, A. and Bagraim, J.J. (2008), "The theory of planned behavior as predictor of entrepreneurial intent amongst final-year university students", South African Journal of Psychology, Vol. 38 No. 4, pp. 711-24.

Goktan, B. and Gunay, G. (2011), "Is Entrepreneurial Cognition Culturally Bound? A Comparative Study Conducted in Turkey and the United States, Journal of Small Business \& Entrepreneurship, Vol.24 No.4, pp.455-470.

Hair, J.F., Black, W.C., Babin, B.J. and Anderson, R.E. (2010), Multivariate Data Analysis, 7th edition. Prentice Hall, Upper Saddle River, NJ.

Hattab, H. (2012), Global Entrepreneurship Monitor (GEM), Egypt Report

Haus, I., Steinmetz, H., Isidor, R. and Kabst, R. (2013), "Gender effects on entrepreneurial intention: a meta-analytical structural equation model", International Journal of Gender and Entrepreneurship, Vol. 5 No. 2, pp. 130-156.

Hayton, J.C., George, G. and Zahara, S.A. (2002), "National culture and entrepreneurship: a review of behavioral research", Entrepreneurship Theory and Practice, Vol. 26 No. 4, pp. 33-53.

Hofstede, G. (1980), Culture's Consequences: International Differences in Work-Related Values, Sage Publications, Beverly Hills, CA.

Hofstede, G. (1981), "Culture and organizations", International Studies of Management and Organization, Vol.10 No.4, pp.15-41.

Hofstede, G. (1998). Masculinity/femininity as a dimension of 
culture. In G. Hofstede (Ed.), Masculinity and femininity: The taboo dimension of national cultures (pp. 3-28). Thousand Oaks, CA: Sage.

Hofstede, G. (2001), Culture's Consequences: Comparing Values, Behaviours, Institutions, and Organizations across Nations, $2^{\text {nd }}$ ed. Thousand Oaks, CA: Sage.

Http://geert-hofstede.com (Accessed April 8 ${ }^{\text {th }}$, 2016).

House, R. Hanges, P. Javidan, M. Dorfman, P. and Gupta, V. (2004), Culture, Leadership, and Organizations: The GLOBE Study of 62 Societies, Sage Publications, Thousand Oaks, CA.

Houston, J.M., Edge, H., Anderson, L.E., Lesmana, C.B. and Suryani, L.K. (2012), "Competitiveness and individualism-collectivism in Bali and the US", North American Journal of Psychology, Vol. 14 No. 1, pp. 163173.

Ismail, A. Tolba, A. and Barakat, S., Global Entrepreneurship Monitor (GEM), Egypt National Report, The American University in Cairo 2016-2017.

Ismail, A. Tolba, A. Barakat, S. Meshreki, H, Global Entrepreneurship Monitor (GEM), Egypt National Report, The American University in Cairo 2017-2018.

Joensuu-Salo, S. Viljamaa, A. and Varamaki, E. (2020), "Do intentions ever die? The temporal stability of entrepreneurial intention and link to behavior", Education + Training, Vol.62 No.3, pp. 325-338.

Iakovleva, T. (2007), Factors Associated with New Venture Performance: The Context of St-Petersburg, PhD series No. 12-2007, Høgskolen i Bodø, Bodø.

Iakovleva, T. Kolvereid, L. and Stephan, U. (2011),"Entrepreneurial intentions in developing and developed countries", Education + Training, Vol. 53, No. 5, pp.353-370.

Jones, P., Jones, A., Packham, G. and Miller, C. (2008), "Student 
attitudes towards enterprise education in Poland: a positive impact", Education + Training, Vol. 50 No. 7, pp. 597-614.

Jöreskog, K.G. and Sörbom, D. (1993), LISREL8: Structural Equation Modelling with the SIMPLIS Command Language, Scientific Software, Chicago.

Karimi, S. Biemans, H. Lans, T. Chizari, M. and Mulder, M. (2014),"Effects of role models and gender on students' entrepreneurial intentions", European Journal of Training and Development, Vol.38 No.8 pp. $694-727$.

Kautonen, T., van Gelderen, M. and Tornikoski, E.T. (2013), "Predicting entrepreneurial behaviour: a test of the theory of planned behaviour", Applied Economics, Vol. 45 No. 6, pp. 697-707.

Kautonen, T., M. van Gelderen, and M. Fink. 2015. "Robustness of the Theory of Planned Behavior in Predicting Entrepreneurial Intentions and Actions." Entrepreneurship Theory \& Practice, Vol.39 No.3, pp.120.

Krueger, N., Reilly, M. and Casrund, A. (2000), "Competing models of entrepreneurial intentions", Journal of Business Venturing, Vol. 15, No.5-6, pp. 411-32.

Levenburg, N. and Schwarz, T. (2008), "Entrepreneurial Orientation among the Youth of India: The Impact of Culture, Education and Environment", The Journal of Entrepreneurship, Vol.17 No.1, pp.15-35.

Liguori, E.W., Bendickson, J.S. and McDowell, W.C. (2018), "Revisiting entrepreneurial intentions: a social cognitive career theory approach", The International Entrepreneurship and Management Journal, Vol. 14 No. 1, pp. 67-78.

Liñán, F. (2005): "Development and validation of an Entrepreneurial Intention Questionnaire (EIQ)", IntEnt05 Conference, Guildford (United Kingdom), 10-13 July.

Liñán, F. and Chen, Y. (2006), "Testing the Entrepreneurial 
Intention Model on a Two Country Sample", Working Paper 06/7, Department of Economics, University of Barcelona.

Liñán, F. and Chen, Y. (2009), "Development and cross-cultural application of a specific instrument to measure entrepreneurial intention", Entrepreneurship Theory and Practice, Vol.33 No.3, pp.594-617.

Litzky, B. Winkel, D. Hance, J. and Howell, R. (2020), "Entrepreneurial intentions: personal and cultural variations", Journal of Small Business and Enterprise Development, Vol.27 No.7, pp.1029-1047.

Lortie, J. and Castogiovanni, G. (2015), "The theory of planned behavior in entrepreneurship research: what we know and future directions", International Entrepreneurship and Management Journal, Vol. 11 No. 4, pp. 935-957.

Maes, J., Leroy, H. and Sels, L. (2014), "Gender differences in entrepreneurial intentions: a TPB multigroup analysis at factor and indicator level", European Management Journal, Vol. 32 No. 5, pp. 784-794.

Maresch, D. Harms, R. Kailer, N. and Wimmer-Wurm, B. (2016), "The Impact of Entrepreneurial Education on the Entrepreneurial Intention of Students in Science and Engineering versus Business Studies University Programs", Technological Forecasting \& Social Change, Vol.104, pp.172-179.

Miranda, F. Chamorro-Meraa, A. and Rubio, S. (2017),

"Academic entrepreneurship in Spanish universities: An analysis of the determinants of entrepreneurial intention", European Research on Management and Business Economics, Vol.23, pp.113-122.

Miralles, F., Giones, F. and Riverola, C. (2015), "Evaluating the impact of prior experience in entrepreneurial intention", International Entrepreneurship and Management Journal, Vol. 12 No. 3, pp. 791-813.

Morales, C. and Holtschlag, C. (2013), "Post materialist values 
and entrepreneurship: a multilevel approach", International Journal of Entrepreneurial Behaviour and Research, Vol. 19 No. 5, pp. 266-282.

Moriano, J.A., Gorgievski, M., Laguna, M., Stephan, U. and Zarafshani, K. (2012), "A cross-cultural approach to understanding entrepreneurial intention", Journal of Career Development, Vol. 39 No. 2, pp. 162-185.

Morris, M.H. and Schindeutte, M. (2005), "Entrepreneurial values and the ethnic enterprise: An examination of six subcultures", Journal of Small Business Management, Vol. 43, pp. 453-79.

Netemeyer, R.G., Bearden, W.O. and Sharma, S. (2003), Scaling Procedures: Issues and Applications, Sage Publications, Thousands Oaks, CA.

Nguyen, H.D., Huy, L. and Boles, T. (2010), "Individualismcollectivism and co-operation: a cross society and crosslevel examination", Negotiation \& Conflict Management Research, Vol. 3 No. 1, pp. 179-204.

Paray, Z. and Kumar, S. (2020), "Does entrepreneurship education influence entrepreneurial intention among students in HEI's? The role of age, gender and degree background", Journal of International Education in Business, Vol. 13 No.1, pp.55-72.

Pruett, M. Shinnar, R. Toney, B. Llopis, F. and Fox, J. (2009),"Explaining Entrepreneurial Intentions of University Students: a Cross-Cultural Study", International Journal of Entrepreneurial Behaviour \& Research, Vol.15 No.6 pp.571-594.

Rauch, A., Frese, M., Wang, Z., Unger, J., Lozada, M., Kupcha, V. and Spirina, T. (2013), "National culture and cultural orientations of owners affecting the innovation-growth relationship in five countries", Entrepreneurship and Regional Development, Vol. 25 No. 9/10, pp. 732-755.

Sesen, H. (2013),"Personality or environment? A comprehensive 
study on the entrepreneurial intentions of university students", Education + Training, Vol. 55, No.7 pp. $624-$ 640.

Shahab, Y., Chengang, Y., Arbizu, A.D. and Haider, M.J. (2019), "Entrepreneurial self-efficacy and intention: do entrepreneurial creativity and education matter?", International Journal of Entrepreneurial Behavior and Research, Vol. 25 No. 2, pp. 259280.

Shinnar, R. Giacomin, O. and Janssen, F. (2012),

"Entrepreneurial Perceptions and Intentions: the Role of Gender and Culture", Entrepreneurship Theory \& Practice, Vol. 36 No. 3, pp. 465-493.

Siu, W. and Lo, E. (2013), "Cultural Contingency in the

Cognitive Model of Entrepreneurial Intention", Entrepreneurship Theory \& Practice, Vol.37 No.2, pp.147-173.

Smith, P.B. (2002), "Levels of analysis in cross-cultural research", in Lonner, W.J., Dinnel, D.L., Hayes, S.A. and Sattler, D.N. (Eds), Online Readings in Psychology and Culture, Unit 2, Chapter 7, Western Washington University, Bellingham, WA, pp. 1-10, available at: www.wwu.edu/Bculture.

Solesvik, M. Westhead, P. Kolvereid, L. and Matlay, H.

(2012),"Student intentions to become self-employed: the Ukrainian context", Journal of Small Business and Enterprise Development, Vol. 19 No. 3 pp. $441-460$.

Solesvik, M. (2013),"Entrepreneurial motivations and intentions: investigating the role of education major", Education + Training, Vol. 55, No.3 pp. $253-271$.

Solesvik, M. Westhead, P. and Matlay, H. (2014), "Cultural factors and entrepreneurial intention", Education + Training, Vol. 56 No. 8/9 pp. 680-696.

Srivastava, S. and Misra, R. (2017) "Exploring antecedents of entrepreneurial intentions of young women in India" A multi-method analysis", Journal of Entrepreneurship in Emerging Economies, Vol.9 No.2, pp.181-206. 
Stephan, U., and Uhlaner, L.M. (2010). Performance-based vs socially supportive culture: A cross-national study of descriptive norms and entrepreneurship. Journal of International Business Studies, Vol.41 No. 8, pp.13471364.

Thompson, E.R. (2009), "Individual Entrepreneurial Intention: Construct Clarification and development of an Internationally Reliable Metric", Entrepreneurship Theory \& Practice, Vol.33 No.3, pp. 669-694.

Thornton, P.H., Ribeiro-Soriano, D., and Urbano, D. (2011), "Socio-cultural factors and entrepreneurial activity: An overview". International Small Business Journal, Vol.29 No.2, pp.105-118.

Tiessen, J.H. (1997), "Individualism, collectivism, and entrepreneurship: a framework for international comparative research", Journal of Business Venturing, Vol. 12 No. 5, pp. 367-384.

Utami, C. (2017), “Attitude, subjective norm, perceived behaviour, entrepreneurship education and self-efficacy toward entrepreneurial intention university student in Indonesia", European Research Studies Journal, Vol. XX No. 2A, pp. 475-494.

Valliere, D. and Peterson, R. (2009), "Entrepreneurship and economic growth: evidence from emerging and developed countries", Entrepreneurship \& Regional Development, Vol. 21 No. 5/6, pp. 459-480.

Valliere, D. (2014),"Culture, values and entrepreneurial motivation in Bhutan", Journal of Enterprising Communities: People and Places in the Global Economy, Vol. 8 No. 2 pp. 126 - 146.

Van Hooft, E. and De Jong, M. (2009), "Predicting Job Seeking for Temporary Employment Using the Theory of Planned Behaviour: The Moderating Role of Individualism and Collectivism", Journal of Occupational and Organizational Psychology, Vol.82 No.2, pp.295-316.

Wakkee, I., Elfring, T. and Monaghan, S. (2010), "Creating 
entrepreneurial employees in traditional service sectors", International Entrepreneurship and Management Journal, Vol. 6 No. 1, pp. 1-21.

$\mathrm{Wu}, \mathrm{S}$. and $\mathrm{Wu}, \mathrm{L}$. (2008), "The impact of higher education on entrepreneurial intentions of university students in China", Journal of Small Business and Enterprise Development, Vol.15 No.4, pp. 752 - 774.

Yang, J. (2013), "The Theory of Planned Behavior and Prediction of Entrepreneurial Intention among Chinese Undergraduates", Social Behavior and Personality, Vol. 41 No.3, pp.367-376.

Yoo, B. Donthu, N. and Lenartowicz, T. (2011), "Measuring Hofstede's Five Dimensions of Cultural Values at the Individual Level: Development and Validation of CVSCALE", Journal of International Consumer Marketing, Vol.23 No.3-4, pp.193-210.

Zeffane, R. (2014), "Does collectivism necessarily negate the spirit of entrepreneurship?" International Journal of Entrepreneurial Behaviour and Research, Vol.20 No.3, pp.278-296. 
the moderating role of individual Rasha H.A. Mostafa Accepted date 18/2/2021

Table (1): Confirmatory Factor Analysis and Cronbach Alpha Results for the Measurement Model (Egypt Sample)

\begin{tabular}{|c|c|c|c|c|}
\hline Constructs & $\begin{array}{c}\text { Factor } \\
\text { loading }\end{array}$ & R-square & $P$-value & $\begin{array}{c}\text { Cronbach } \\
\text { Alpha } \\
\end{array}$ \\
\hline Subjective Norms (SN) (3) & & & & .70 \\
\hline SN1 & .661 & 0.437 & $* * *$ & \\
\hline SN2 & .684 & 0.468 & $* * *$ & \\
\hline SN3 & .645 & 0.416 & $* * *$ & \\
\hline EI (6) & & & & .76 \\
\hline EI 1 & .714 & 0.510 & $* * *$ & \\
\hline EI 2 & .659 & 0.434 & $* * *$ & \\
\hline EI 3 & .680 & 0.462 & $* * *$ & \\
\hline EI 5 & .683 & 0.466 & $* * *$ & \\
\hline ATE (5) & & & & .74 \\
\hline ATE1 & .644 & 0.415 & $* * *$ & \\
\hline ATE2 & .804 & 0.646 & $* * *$ & \\
\hline ATE4 & .652 & 0.425 & $* * *$ & \\
\hline PBC (6) & & & & .77 \\
\hline PBC1 & .584 & 0.341 & $* * *$ & \\
\hline $\mathrm{PBC} 2$ & .710 & 0.504 & $* * *$ & \\
\hline PBC3 & .631 & 0.398 & $* * *$ & \\
\hline PBC4 & .710 & 0.504 & $* * *$ & \\
\hline PBC5 & .600 & 0.360 & $* * *$ & \\
\hline PD (5) & & & & .80 \\
\hline PD1 & .672 & 0.452 & $* * *$ & \\
\hline PD2 & .708 & 0.501 & $* * *$ & \\
\hline PD3 & .782 & 0.612 & $* * *$ & \\
\hline PD4 & .539 & 0.291 & $* * *$ & \\
\hline PD5 & .654 & 0.428 & $* * *$ & \\
\hline UA (5) & & & & .78 \\
\hline UA2 & .568 & 0.323 & $* * *$ & \\
\hline UA3 & .700 & 0.490 & $* * *$ & \\
\hline UA4 & .752 & 0.566 & $* * *$ & \\
\hline UA5 & .765 & 0.585 & $* * *$ & \\
\hline MAS (4) & & & & .70 \\
\hline MAS1 & .514 & 0.264 & $* * *$ & \\
\hline MAS2 & .649 & 0.421 & $* * *$ & \\
\hline MAS3 & .700 & 0.490 & $* * *$ & \\
\hline
\end{tabular}

Note: SN - social norms; EI - entrepreneurial intention, ATT - attitude; PBC perceived behavioral control; PD - power distance; UA - uncertainty avoidance; MAS - masculinity $* * * p<0.001$ 
the moderating role of individual Rasha H.A. Mostafa Accepted date 18/2/2021

Table (2): Confirmatory Factor Analysis and Cronbach Alpha Results for the Measurement Model (Scotland Sample)

\begin{tabular}{|c|c|c|c|c|}
\hline Constructs & Factor loading & R-square & $P$-value & Cronbach Alpha \\
\hline Subjective Norms (SN) (3) & & & & .70 \\
\hline SN1 & 0.544 & 0.296 & $* * *$ & \\
\hline $\mathrm{SN} 2$ & 0.765 & 0.585 & $* * *$ & \\
\hline SN3 & 0.658 & 0.433 & $* * *$ & \\
\hline EI (6) & & & & .94 \\
\hline EI 1 & 0.694 & 0.482 & $* * *$ & \\
\hline EI 2 & 0.893 & 0.797 & $* * *$ & \\
\hline EI 3 & 0.857 & 0.734 & $* * *$ & \\
\hline EI 4 & 0.935 & 0.874 & & \\
\hline EI 5 & 0.741 & 0.549 & $* * *$ & \\
\hline EI 6 & 0.913 & 0.834 & & \\
\hline ATE (5) & & & & .90 \\
\hline ATE1 & 0.746 & 0.557 & $* * *$ & \\
\hline ATE2 & 0.908 & 0.824 & $* * *$ & \\
\hline ATE3 & 0.816 & 0.666 & & \\
\hline ATE4 & 0.829 & 0.687 & $* * *$ & \\
\hline PBC (6) & & & & .79 \\
\hline PBC1 & 0.619 & 0.383 & $* * *$ & \\
\hline PBC3 & 0.740 & 0.548 & $* * *$ & \\
\hline PBC5 & 0.735 & 0.540 & $* * *$ & \\
\hline PBC6 & 0.712 & 0.507 & $* * *$ & \\
\hline PD (5) & & & & .77 \\
\hline PD1 & 0.500 & 0.213 & $* * *$ & \\
\hline PD2 & 0.560 & 0.314 & $* * *$ & \\
\hline PD3 & 0.784 & 0.615 & $* * *$ & \\
\hline PD4 & 0.716 & 0.513 & $* * *$ & \\
\hline PD5 & 0.674 & 0.454 & $* * *$ & \\
\hline UA (5) & & & & .80 \\
\hline UA2 & 0.708 & 0.501 & $* * *$ & \\
\hline UA3 & 0.838 & 0.702 & $* * *$ & \\
\hline UA4 & 0.609 & 0.371 & $* * *$ & \\
\hline UA5 & 0.716 & 0.513 & $* * *$ & \\
\hline MAS (4) & & & & .76 \\
\hline MAS1 & 0.725 & 0.526 & $* * *$ & \\
\hline MAS2 & 0.694 & 0.482 & $* * *$ & \\
\hline MAS3 & 0.729 & 0.531 & $* * *$ & \\
\hline
\end{tabular}

Note: SN - social norms; EI - entrepreneurial intention, ATT - attitude; PBC perceived behavioral control; PD - power distance; UA - uncertainty avoidance; MAS - masculinity $* * * p<0.001$ 
Table (3): Correlation Coefficients among the Constructs and

Discriminant and Convergent Validity of the Study Variables (Egypt Sample)

\begin{tabular}{|c|c|c|c|c|c|c|c|c|c|c|c|}
\hline & Mean & SD & CR & AVE & SN & EI & ATT & PBC & PD & UA & MAS \\
\hline SN & 4.03 & .696 & .702 & .440 & 1 & & & & & & \\
\hline EI & 3.68 & .927 & .779 & .468 & .013 & 1 & & & & & \\
\hline ATE & 3.58 & .924 & .744 & .495 & .016 & $.360^{* *}$ & 1 & & & & \\
\hline PBC & 2.85 & .838 & .783 & .421 & .001 & $.143^{* *}$ & $.108^{* *}$ & $\mathbf{1}$ & & & \\
\hline PD & 2.38 & 1.006 & .806 & .457 & .001 & .003 & .001 & $.052^{* *}$ & 1 & & \\
\hline UA & 3.86 & .8549 & .792 & .491 & .014 & $.070^{* *}$ & $.090^{* *}$ & .015 & -.004 & 1 & \\
\hline MAS & 2.83 & 1.063 & .655 & .392 & - & .014 & .006 & $.067^{* *}$ & $.051^{* *}$ & .011 & 1 \\
\hline
\end{tabular}

Notes: $\mathrm{CR}>0.70, \mathrm{AVE}>0.5, * *$ correlation is significant at the 0.01 level (2-tailed), * correlation is significant at the 0.05 level (2-tailed), SN - social norms; EI - entrepreneurial intentions, ATE - attitude towards entrepreneurship; PBC - perceived behavioral control; PD - power distance; UA - uncertainty avoidance; MAS - masculinity

Table (4): Correlation Coefficients among the Constructs and Discriminant and Convergent Validity of the Study Variables

(Scotland Sample)

\begin{tabular}{|l|c|c|c|c|c|c|c|c|c|c|c|}
\hline & Mean & SD & CR & AVE & SN & EI & ATT & PBC & PD & UA & MAS \\
\hline SN & 4.057 & .6315 & .697 & .438 & 1 & & & & & & \\
\hline EI & 3.080 & 1.0374 & .936 & .712 & .001 & 1 & & & & & \\
\hline ATE & 3.609 & .9491 & .896 & .684 & .002 & $.624^{* *}$ & 1 & & & & \\
\hline PBC & 2.945 & .8148 & .796 & .494 & .001 & $.331^{* *}$ & $.320^{* *}$ & $\mathbf{1}$ & & & \\
\hline PD & 1.819 & .6438 & .779 & .422 & -.011 & .005 & -.001 & .005 & 1 & & \\
\hline UA & 3.692 & .5988 & .812 & .522 & .009 & -.003 & -.003 &. & .001 & & \\
\hline MAS & 1.720 & .8174 & .759 & .513 & - & .001 & -.003 & .001 & $.215^{* *}$ & .006 & 1 \\
\hline
\end{tabular}

Notes: $\mathrm{CR}>0.70$, AVE $>0.5, * *$ correlation is significant at the 0.01 level (2-tailed), * correlation is significant at the 0.05 level (2-tailed), SN - social norms; EI - entrepreneurial intentions, ATE - attitude towards

entrepreneurship; PBC - perceived behavioral control; PD - power distance; UA - uncertainty avoidance; MAS -

masculinity 
Table (5): Path coefficients and significances (Egypt Sample)

\begin{tabular}{|c|c|c|c|c|c|}
\hline HP & Structural Paths & $\begin{array}{c}\text { Path } \\
\text { Coefficient }\end{array}$ & $\begin{array}{c}\text { t- } \\
\text { value }\end{array}$ & $\boldsymbol{P}$ & \\
\hline HP1 & Attitude $\rightarrow$ EI & .697 & 6.523 & $* * *$ & Accepted \\
\hline HP2 & Subjective norms $\rightarrow$ EI & .053 & .813 & $.416^{\mathrm{ns}}$ & Rejected \\
\hline HP3 & $\begin{array}{l}\text { Perceived behavioral } \\
\text { control } \rightarrow \text { EI }\end{array}$ & .186 & 2.492 & $.013 *$ & Accepted \\
\hline \multicolumn{6}{|c|}{$\begin{array}{l}\text { Model Fit indices: } \\
\{\chi 2 / \mathrm{d} f(103.831 / 84 ; p=.07) ; \mathrm{NFI}(.90) ; \mathrm{CFI}(0.97) ; \mathrm{TLI}(0.97) ; \mathrm{RMSEA} \\
(.03) ; \mathrm{IFI}(0.98) ; \mathrm{PCFI}(0.79) \\
* * * p<0.001 ; * p<0.01 ; \mathrm{ns}=\text { not significant }\end{array}$} \\
\hline
\end{tabular}

Table (6): Path coefficients and significances (Scotland Sample)

\begin{tabular}{|c|c|c|c|c|c|}
\hline HP & Structural Paths & $\begin{array}{c}\text { Path } \\
\text { Coefficient }\end{array}$ & $\begin{array}{c}\text { t- } \\
\text { value }\end{array}$ & $\boldsymbol{P}$ & \\
\hline HP1 & Attitude $\rightarrow$ EI & .777 & 8.641 & $* * *$ & Accepted \\
\hline HP2 & Subjective norms $\rightarrow$ EI & -.059 & -1.04 & $.298^{\mathrm{ns}}$ & Rejected \\
\hline HP3 & $\begin{array}{l}\text { Perceived behavioral } \\
\text { control } \rightarrow \text { EI }\end{array}$ & .128 & 1.585 & $\begin{array}{r}.113 \\
\text { ns }\end{array}$ & Rejected \\
\hline \multicolumn{6}{|c|}{$\begin{array}{l}\text { Model Fit indices: } \\
\{\chi 2 / \mathrm{d} f(125.51 / 113, p=.198) ; \mathrm{NFI}(.933) ; \mathrm{CFI}(0.99) ; \mathrm{TLI}(0.99) ; \\
\text { RMSEA (.02); IFI }(0.99) ; \text { PCFI }(0.83) \\
* * * p<0.001 ; \text { ns = not significant }\end{array}$} \\
\hline
\end{tabular}


the moderating role of individual Rasha H.A. Mostafa Accepted date 18/2/2021

Table (7): The Differences between Egyptian and Scottish,

UK Students with Respect to TPB Predictors,

Entrepreneurial Intentions and Cultural Values

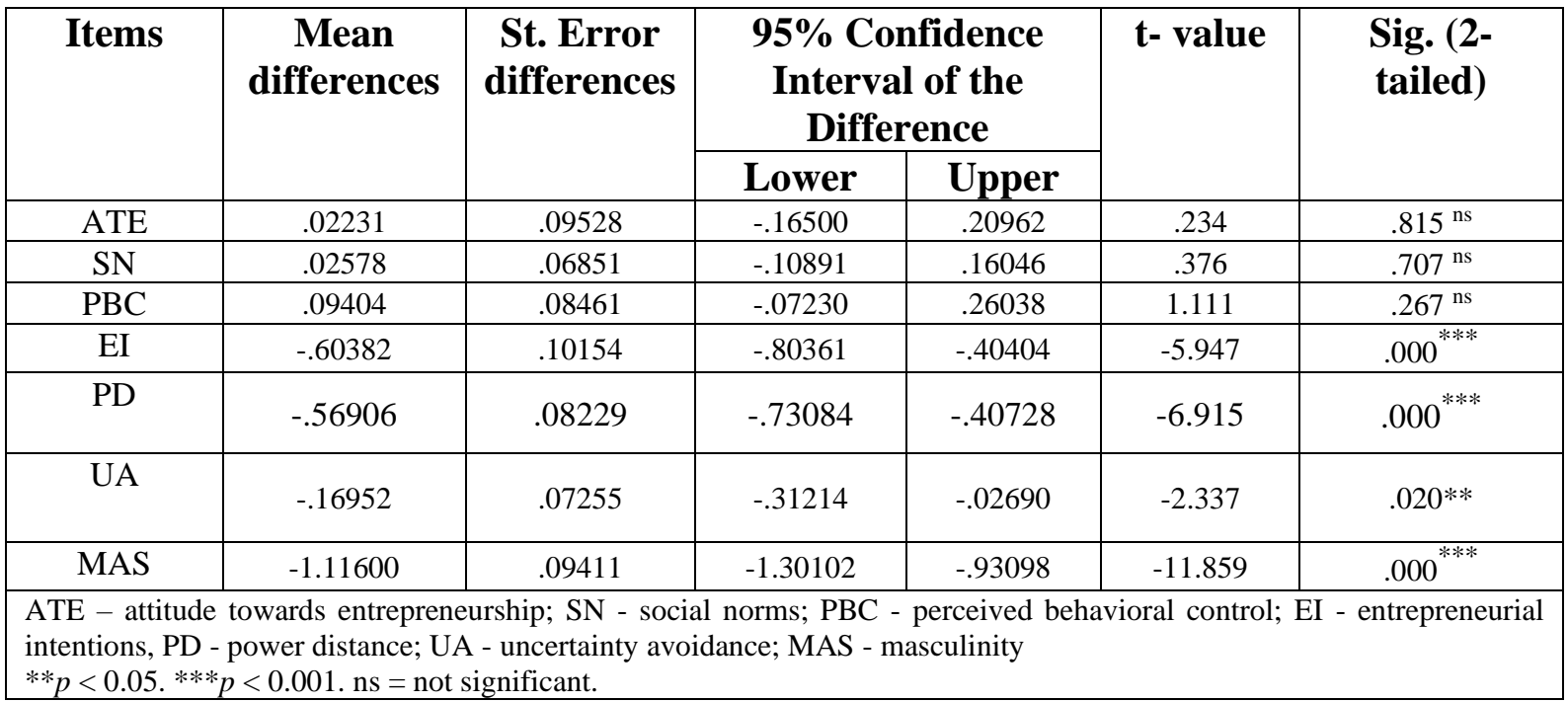


the moderating role of individual Rasha H.A. Mostafa Accepted date 18/2/2021

Table (8): Moderating effect of Power Distance (PD) among Egyptian Students

\begin{tabular}{|c|c|c|c|c|c|c|c|}
\hline & & \multicolumn{6}{|c|}{ Coefficient (Median point 2.2) } \\
\hline Hypothesis & $\begin{array}{l}\text { Structural } \\
\text { Path }\end{array}$ & \multicolumn{3}{|c|}{ Low PD (n =114) } & \multicolumn{3}{|c|}{ High PD (n =129) } \\
\hline & $\mathrm{ATE} \rightarrow \mathrm{EI}$ & \multicolumn{3}{|c|}{$.729^{* * *}$} & \multicolumn{3}{|c|}{$.616^{* * *}$} \\
\hline & $\mathrm{SN} \rightarrow \mathrm{EI}$ & \multicolumn{3}{|c|}{$-.051^{\mathrm{ns}}$} & \multicolumn{3}{|c|}{$.170^{\mathrm{ns}}$} \\
\hline & $\mathrm{PBC} \rightarrow \mathrm{EI}$ & \multicolumn{3}{|c|}{$.254^{* *}$} & \multicolumn{3}{|c|}{$.100^{\mathrm{ns}}$} \\
\hline & \multicolumn{6}{|c|}{ Goodness of fit statistics } & Results \\
\hline Model & $\chi^{2}$ & df & $\mathrm{P}$-value & CFI & NFI & RMSEA & \\
\hline Unconstrained & 247.743 & 168 & .000 & .923 & .801 & .044 & \\
\hline Constrained & 262.676 & 183 & .000 & .923 & .789 & .043 & \\
\hline Difference & 14.933 & 15 & $0.456^{\mathrm{ns}}$ & & & & $\begin{array}{l}\text { Not } \\
\text { Significant } \\
\text { at } 0.05\end{array}$ \\
\hline
\end{tabular}

Table (9): Moderating effect of Uncertainty Avoidance (UA) among Egyptian Students

\begin{tabular}{|c|c|c|c|c|c|c|c|}
\hline & & \multicolumn{6}{|c|}{ Coefficient (Median point 4) } \\
\hline Hypothesis & $\begin{array}{l}\text { Structural } \\
\text { Path }\end{array}$ & \multicolumn{3}{|c|}{ Low UA $(n=110)$} & \multicolumn{3}{|c|}{ High UA (n =133) } \\
\hline & ATE $\rightarrow$ EI & \multicolumn{3}{|c|}{$.655^{* * *}$} & \multicolumn{3}{|c|}{$.674^{* * *}$} \\
\hline & $\mathrm{SN} \rightarrow \mathrm{EI}$ & \multicolumn{3}{|c|}{$-.016^{\mathrm{ns}}$} & \multicolumn{3}{|c|}{$.063^{\mathrm{ns}}$} \\
\hline & $\mathrm{PBC} \rightarrow \mathrm{EI}$ & \multicolumn{3}{|c|}{$.086^{\mathrm{ns}}$} & \multicolumn{3}{|c|}{$.267^{* *}$} \\
\hline & \multicolumn{6}{|c|}{ Goodness of fit statistics } & Results \\
\hline Model & $\chi^{2}$ & df & P-value & CFI & NFI & RMSEA & \\
\hline Unconstrained & 218.625 & 168 & .005 & .948 & .817 & .035 & \\
\hline Constrained & 232.533 & 183 & .008 & .950 & .805 & .034 & \\
\hline Difference & 13.908 & 15 & $0.533^{\text {ns }}$ & & & & $\begin{array}{l}\text { Not } \\
\text { Significant } \\
\text { at } 0.05\end{array}$ \\
\hline
\end{tabular}

$* * p<0.05 ; * * * p<0.001 ; \mathrm{ns}=$ not significant. 
the moderating role of individual Rasha H.A. Mostafa Accepted date 18/2/2021

Table (10): Moderating effect of Masculinity (MAS) among Egyptian Students

\begin{tabular}{|c|c|c|c|c|c|c|c|}
\hline & & & \multicolumn{5}{|c|}{ Coefficient (Median point 3) } \\
\hline Hypothesis & \multicolumn{2}{|c|}{ Structural Path } & \multicolumn{3}{|c|}{ Low MAS $(n=116)$} & \multicolumn{2}{|c|}{ High MAS $(n=127)$} \\
\hline & \multicolumn{2}{|c|}{$\mathrm{ATE} \rightarrow \mathrm{EI}$} & \multicolumn{3}{|c|}{$.933^{* * *}$} & \multicolumn{2}{|l|}{$.526^{* * *}$} \\
\hline & \multicolumn{2}{|c|}{$\mathrm{SN} \rightarrow \mathrm{EI}$} & \multicolumn{3}{|c|}{$-.045^{\mathrm{ns}}$} & \multicolumn{2}{|l|}{$.116^{\mathrm{ns}}$} \\
\hline & \multicolumn{2}{|c|}{$\mathrm{PBC} \rightarrow \mathrm{EI}$} & \multicolumn{3}{|c|}{$-.006^{\mathrm{ns}}$} & \multicolumn{2}{|l|}{$.305^{*}$} \\
\hline & \multicolumn{6}{|c|}{ Goodness of fit statistics } & Results \\
\hline Model & $\chi^{2}$ & $\mathrm{df}$ & $\begin{array}{c}\mathrm{P}- \\
\text { value }\end{array}$ & $\mathrm{CFI}$ & NFI & RMSEA & \\
\hline Unconstrained & 200.939 & 168 & .042 & .966 & .828 & .029 & \\
\hline Constrained & 214.794 & 183 & .054 & .967 & .816 & .027 & \\
\hline Difference & 13.855 & 15 & 0.537 & & & & $\begin{array}{l}\text { Not Significant at } \\
0.05\end{array}$ \\
\hline
\end{tabular}

$* p<0.01 ; * * * p<0.001 ; \mathrm{ns}=$ not significant.

Table (11): Moderating effect of Power Distance (PD) among Scottish Students

\begin{tabular}{|c|c|c|c|c|c|c|c|}
\hline & & & \multicolumn{5}{|c|}{ Coefficient (Median point 1.8) } \\
\hline Hypothesis & \multicolumn{2}{|c|}{ Structural Path } & \multicolumn{3}{|c|}{ Low PD $(\mathrm{n}=69)$} & \multicolumn{2}{|c|}{ High PD $(n=90)$} \\
\hline & \multicolumn{2}{|c|}{ ATE $\rightarrow$ EI } & \multicolumn{3}{|c|}{$.826^{* * *}$} & \multicolumn{2}{|c|}{$.724^{* * * *}$} \\
\hline & \multicolumn{2}{|c|}{$\mathrm{SN} \rightarrow \mathrm{EI}$} & \multicolumn{3}{|c|}{$-.169^{* *}$} & \multicolumn{2}{|c|}{$.062^{\mathrm{ns}}$} \\
\hline & \multicolumn{2}{|c|}{$\mathrm{PBC} \rightarrow \mathrm{EI}$} & \multicolumn{3}{|c|}{$.051^{\mathrm{ns}}$} & \multicolumn{2}{|c|}{$.209^{\mathrm{ns}}$} \\
\hline & \multicolumn{6}{|c|}{ Goodness of fit statistics } & Results \\
\hline Model & $\chi^{2}$ & $\mathrm{df}$ & $\begin{array}{c}\mathrm{P}- \\
\text { value }\end{array}$ & CFI & NFI & RMSEA & \\
\hline Unconstrained & 291.919 & 226 & .002 & .963 & .859 & .043 & \\
\hline Constrained & 305.806 & 243 & .004 & .965 & .852 & .041 & \\
\hline Difference & 13.887 & 17 & 0.675 & & & & $\begin{array}{l}\text { Not Significant at } \\
0.05\end{array}$ \\
\hline
\end{tabular}

$* * p<0.05 . * * * p<0.001 . \mathrm{ns}=$ not significant. 
the moderating role of individual $\quad$ Rasha H.A. Mostafa Accepted date 18/2/2021

Table (12): Moderating effect of Uncertainty Avoidance (UA) among Scottish Students

\begin{tabular}{|c|c|c|c|c|c|c|c|}
\hline & & & & \multicolumn{4}{|c|}{ Coefficient (Median point 3.75) } \\
\hline Hypothesis & \multicolumn{3}{|c|}{ Structural Path } & \multicolumn{2}{|c|}{$\begin{array}{l}\text { Low UA } \\
(n=65)\end{array}$} & \multicolumn{2}{|c|}{ High UA (n =94) } \\
\hline & \multicolumn{3}{|c|}{$\mathrm{ATE} \rightarrow \mathrm{EI}$} & \multicolumn{2}{|c|}{$.729^{* * *}$} & \multicolumn{2}{|c|}{$.811^{* * * *}$} \\
\hline & \multicolumn{3}{|c|}{$\mathrm{SN} \rightarrow \mathrm{EI}$} & \multicolumn{2}{|c|}{$.068^{\mathrm{ns}}$} & \multicolumn{2}{|c|}{$-.072^{\mathrm{ns}}$} \\
\hline & \multicolumn{3}{|c|}{$\mathrm{PBC} \rightarrow \mathrm{EI}$} & \multicolumn{2}{|c|}{$.125^{\mathrm{ns}}$} & \multicolumn{2}{|c|}{$.113^{\mathrm{ns}}$} \\
\hline & \multicolumn{6}{|c|}{ Goodness of fit statistics } & Results \\
\hline Model & $\chi^{2}$ & df & $P$-value & CFI & NFI & RMSEA & \\
\hline Unconstrained & 313.398 & 226 & .000 & .952 & .850 & .050 & \\
\hline Constrained & 334.587 & 243 & .000 & .949 & .840 & .049 & \\
\hline Difference & 21.189 & 17 & 0.218 & & & & $\begin{array}{l}\text { Not } \\
\text { Significant at } \\
0.05\end{array}$ \\
\hline
\end{tabular}

$* * * p<0.001 . \mathrm{ns}=$ not significant.

Table (13): Moderating effect of Masculinity (MAS) among Scottish Students

\begin{tabular}{|c|c|c|c|c|c|c|c|}
\hline & & & & \multicolumn{4}{|c|}{ Coefficient (Median point 1.34) } \\
\hline Hypothesis & \multicolumn{3}{|c|}{ Structural Path } & \multicolumn{2}{|c|}{$\begin{array}{l}\text { Low MAS } \\
(\mathrm{n}=59)\end{array}$} & \multicolumn{2}{|c|}{ High MAS (n =100) } \\
\hline & \multicolumn{3}{|c|}{$\mathrm{ATE} \rightarrow \mathrm{EI}$} & \multicolumn{2}{|c|}{$.889^{* * *}$} & \multicolumn{2}{|l|}{$.716^{* * *}$} \\
\hline & \multicolumn{3}{|c|}{$\mathrm{SN} \rightarrow \mathrm{EI}$} & \multicolumn{2}{|c|}{$-.039^{\mathrm{ns}}$} & \multicolumn{2}{|c|}{$-.066^{\mathrm{ns}}$} \\
\hline & \multicolumn{3}{|c|}{$\mathrm{PBC} \rightarrow \mathrm{EI}$} & \multicolumn{2}{|c|}{$-.035^{\mathrm{ns}}$} & \multicolumn{2}{|c|}{$.218^{* *}$} \\
\hline & \multicolumn{6}{|c|}{ Goodness of fit statistics } & Results \\
\hline Model & $\chi^{2}$ & df & $\begin{array}{c}P- \\
\text { value }\end{array}$ & CFI & NFI & RMSEA & \\
\hline Unconstrained & 269.751 & 226 & .024 & .975 & .866 & .035 & \\
\hline Constrained & 282.076 & 243 & .043 & .978 & .860 & .032 & \\
\hline Difference & 12.325 & 17 & 0.780 & & & & $\begin{array}{l}\text { Not } \\
\text { Significant at } \\
0.05\end{array}$ \\
\hline
\end{tabular}

$* * p<0.05 . * * * p<0.001 . \mathrm{ns}=$ not significant. 
the moderating role of individual Rasha H.A. Mostafa Accepted date 18/2/2021

Table (14): Moderating effect of Nationality among TPB Predictors and Entrepreneurial Intention

\begin{tabular}{|c|c|c|c|c|c|c|c|}
\hline & & & & & \multicolumn{3}{|c|}{ Coefficient } \\
\hline Hypothesis & \multicolumn{4}{|c|}{ Structural Path } & $\begin{array}{l}\text { Egyptian } \\
(\mathrm{n}=\mathbf{2 4 3})\end{array}$ & \multicolumn{2}{|c|}{$\begin{array}{c}\text { Scottish } \\
(n=159)\end{array}$} \\
\hline & \multicolumn{4}{|c|}{ ATE $\rightarrow$ EI } & $.783 * * *$ & \multicolumn{2}{|c|}{$.653 * * *$} \\
\hline & \multicolumn{4}{|c|}{$\mathrm{SN} \rightarrow \mathrm{EI}$} & $.035^{\mathrm{ns}}$ & \multicolumn{2}{|c|}{$-.069^{\mathrm{ns}}$} \\
\hline & \multicolumn{4}{|c|}{$\mathrm{PBC} \rightarrow \mathrm{EI}$} & $.107^{\mathrm{ns}}$ & \multicolumn{2}{|l|}{$.271 * *$} \\
\hline & \multicolumn{6}{|c|}{ Goodness of fit statistics } & Results \\
\hline Model & $\chi^{2}$ & $\mathrm{df}$ & $P$-value & CFI & NFI & RMSEA & \\
\hline Unconstrained & 246.910 & 168 & .000 & .965 & .899 & .034 & \\
\hline Constrained & 279.858 & 183 & .000 & .956 & .885 & .036 & \\
\hline Difference & 32.948 & 15 & 0.005 & & & & $\begin{array}{l}\text { Significant } \\
\text { at } 0.05\end{array}$ \\
\hline
\end{tabular}


